\title{
Differentiation of Administrative Units of Albania by Length and Density of National Road Network
}

\author{
Ibrahim Ramadani $^{1}$ \\ Pal Nikolli ${ }^{2}$ \\ Ferim Gashi ${ }^{1 *}$ \\ ${ }^{1}$ University of Prishtina, Prishtina, Kosovo \\ ${ }^{2}$ University of Tirana, Tirana, Albania \\ ${ }^{*}$ Corresponding Author
}

Doi: 10.36941/ajis-2019-0026

\begin{abstract}
The distribution of the road network in Albania is condition by physico-geographic and socio-economic factors. The small density of the road network puts Albania in the last group of world countries, together with Romania and Bulgaria, but behind all Balkan countries. The unequal development of the road network is one of the strongest reasons for the unequal economic development of different regions of Albania. Inadequacy of road infrastructure is also a major cause for the high level of pollution in urban areas. The study assesses and differentiates Albania's national road network based on several statistical indicators, according to the administrative organization (municipalities and districts) approved by law. The data sources are the road and topographic maps, as well as the data of the Ministry of Transport and Infrastructure and the Ministry of Local Affairs. Maps and images are georeferenced and processed in ArcGIS 10.2, where digital lines, road junctions, and other geographic objects related to them are digitized.
\end{abstract}

Keywords: road network, district, municipality, differentiation, uneven development

\section{Introduction}

Because of the multi-dimensional functions, the importance of maintaining relationships and achieving integration in every aspect of society, ranging from individual to nation, a compulsory feature of modern life is the transport, movement and exchange of people, goods and services (Umoren et al. 2009). Roads, widespread as "veins" and "arteries" in all countries of the world, have brought about considerable development (Badiger \& Badiger 2003). They are an important component of development, with complex economic, social and ecological impacts.

Improving transport through road networks leads to increased regional specialization by reducing transport costs. Concentrated economies, not only in large cities but also in rural areas, are accelerating their growth, expanding markets, and increasing the dominance of the transport system.

The importance of road infrastructure for socio-economic development of a region is already known. In many developing countries, outdated or inefficient transport networks are an expected barrier to economic growth. Many studies have shown that an enhanced and improved road network (e.g., primary, secondary and tertiary) can provide opportunities for growth and development through: reducing transport, consumption and production costs of goods and services; 
the increase of agricultural and livestock products through the encouragement of a broader approach and the use of modern inputs; improving access to markets, and reducing input prices and agricultural products, etc. (Steiner and Butler 2007). However, the role of the railroad in promoting economic development and spatial transformation is extraordinary. There are a number of empirical studies showing increased land value due to railways in developed and undeveloped area-countries (Bollinger and Ihlanfeldt 1997; Banister and Berechman 2001; Laakso 1992; Cervero 2003; Garrett 2004; Yankaya 2004; Armstrong and Rodriguez 2006; Du and Mulley 2007; Atack et al. 2010; Medda and Modelewska 2010; Mclntosh et al. 2014; Mulley 2014; Anantsuksomsri and Tontisirin 2015; Sharma and Newman 2017; Zhong and Li 2016; Sun et al. 2017).

The road infrastructure in Albania, in the technical aspect of the word, began to be builted during the First World War when the warring powers located in Albania for their needs built road axes that still exist today. Here, the Austrians are distinguished, who managed to put into operation, also the decauville Shkodra-Vora and Rrogozhina. At the time of King Zog, almost all major cities were connected by roadways, which were then paved with the arrival of Italy.

In the years 1945-1992, the development of the road network in Albania was conditioned by specific conditions. Traffic was dominate by large vehicles of transportation of goods where there was no light vehicles of transport, while the world experience shows that the heavy traffic ratio with light traffic should be $15-20 \%$ with $80-85 \%$. In Albania, in the absence of private property on vehicles, this report was the opposite.

Until 1945, the total road network was $2800 \mathrm{~km}$, of which only $400 \mathrm{~km}$ were paved roads. Whereas, in 1990, the length of the road network reached $7450 \mathrm{~km}$, of which $2850 \mathrm{~km}$ were paved roads.

Today, there are data that do not entirely match the length of the national road network in Albania. But, according to the Ministry of Transport, currently the Albanian road network has a total length of approximately $18,000 \mathrm{~km}$. (Of which $3794 \mathrm{~km}$ are defined as national roads). The main road network is about $1796 \mathrm{~km}$ long with nine main links making up the base network, while the secondary network is $1998 \mathrm{~km}$ long.

The linear length of the road, as an important element of human geography and the density of the road network $(\mathrm{km} / \mathrm{km} 2)$, are critical evaluation indexes to reflect the overall number and level of road construction, often used to control rationality of the distribution of the road network and to verify if the plan / project is correctly balanced. The density of the road network is also one of the decisive factors in the choosing of roads in the generalization of the map.

Road density is a widely useful road network index in a landscape and is also associated with some ecological effects of roads (Seiler 2001; Forman et al. 2003). Road network density analysis is an important method of spatial analysis, and is widely used in intelligent transport, urban planning, and auto mapping general scenarios. Also, the density of the road network best reflects the dependence of the current transport infrastructure on morphodynamic factors. This indicator reflects the anthropogenic pressures exercised in the natural area (Herman 2009).

\section{Brief Historical Overview of the Development of the Road Network in Albania}

The history of the development of the road network in Albania is closely related to the geographic position as a crossroad from East to West and vice versa, the history of our people, its socioeconomic relations, the ties that the various provinces of the country had between them and neighboring countries in the Balkans and beyond the Adriatic, the forms of the physical surface of the earth, etc. Albania, not only has a very wide coastal area from Shkodra to Vlora, but with the valleys of Drini, Shkumbini, Devoll, Vjosa etc., it is connected with the interior of the Balkans peninsula and hence with the East. Along these valleys, in ancient times, the main roads of the country that served both for economic exchanges and as strategic-military roads were developed.

In the antiquity, we highlight the Egnatia road in the valley of Shkumbini, which served for economic exchanges between the Adriatic, the Aegean Sea, the Black Sea and the Danube. This road had two starting points: one in Durres and the other in Apollonia. In addition, there were other roads connecting the cities of Illyria, such as the road connecting Durrës with Apollonia, the road 
along the Vjosa valley, the Apoloni - Vlorë - Orikum - Llogara - Finiq - Butrint road Narona Shkodra - Lezha, Shkodra - Vau i Dejes - Lezha - Durrës, Lezha - Vau i Dejes - Pukë - Kosovo, etc.

In the period between II and XII centuries, the streets and the cities of Albania had more military significance. After the XII century, the character of the streets changed; from the street of strategic importance to the streets of commercial importance. At this time, the old roads gained new significance and new roads were started up to the needs of that time.

With theTurkish occupation, some of the streets and cities were either deserted or lost their importance. Therefore, the streets of our country after the Turkish occupation are nothing more than a continuation of medieval roads. At the end of XVIII century the road network of Albania is expanded; among the main roads we can mention: the road Shkodër - Drisht - Shkodër - Pulaj Shkodër - Lezhë - Lezhë - Orosh - Durrës - Fushë e Tiranës - Dibër the road on Qafë e Kërrabës, Elbasan - Berat - Përmet, Durrës - Vlora, Korça - Kolonjë - Janina, the road along the Vjosa and Drino valleys, etc.

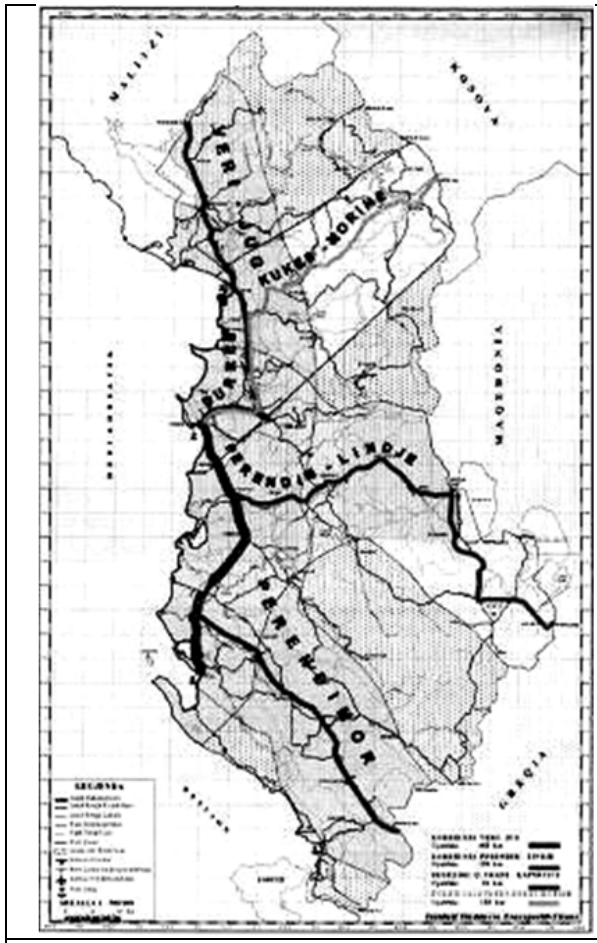

Figure 1. Main corridors and transport ramifications in the territory of Albania Source: Revista "Transporti", Nr. 2, viti 2006. IST, Tiranë

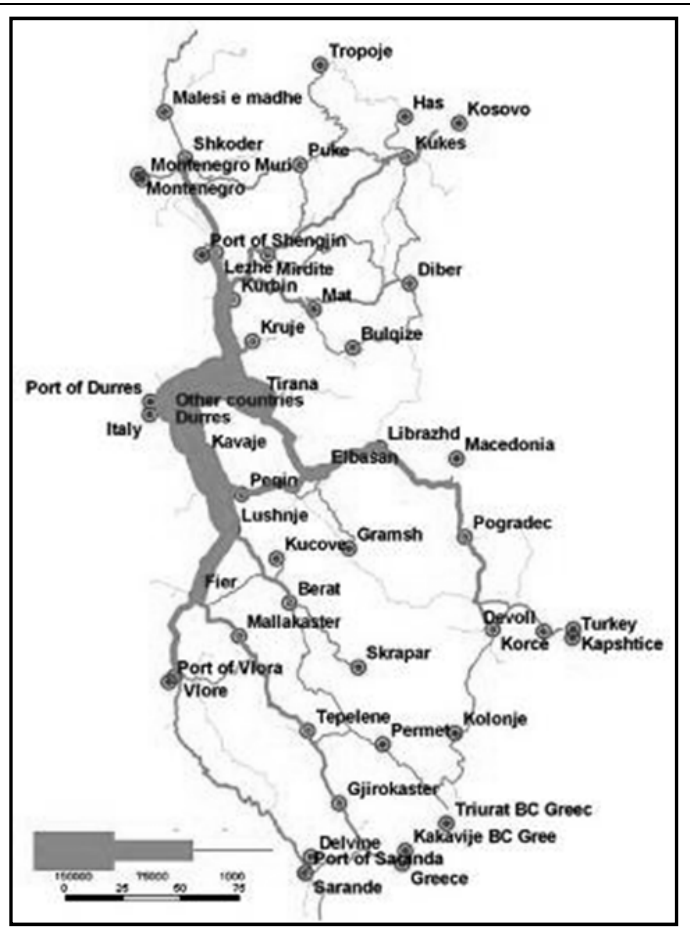

Figure 2. Goods Movement in the Road Network for 2010 (Thousand Tons / Year)

Source: First Five Years Review of the Albanian National Transport Plan (antp). European Commission Europeaid / 127468 / c / ser / al Draft Final Report part I June 2010. This project is funded by the European Union. Louis Berger

After the 90s, studies were conducted on the possibility of developing corridors and transport ramifications in the territory of Albania. Here we mention: Trans-European corridor, West-East (Durres - Tirana - Elbasan - Qafë Thanë - Lin); National North-South corridor (Hani i Hotit - Shkodër - Tirana - Durrës - Rrogozhinë - Fier - Tepelenë - Gjirokastër - Kakavijë); the regional corridor (Durrës - Kukës - Morinë), etc., (map 1). The largest amount of goods and the largest number of passengers circulating in Albania coincides with the direction of these corridors (map 2 and map 3 ). 


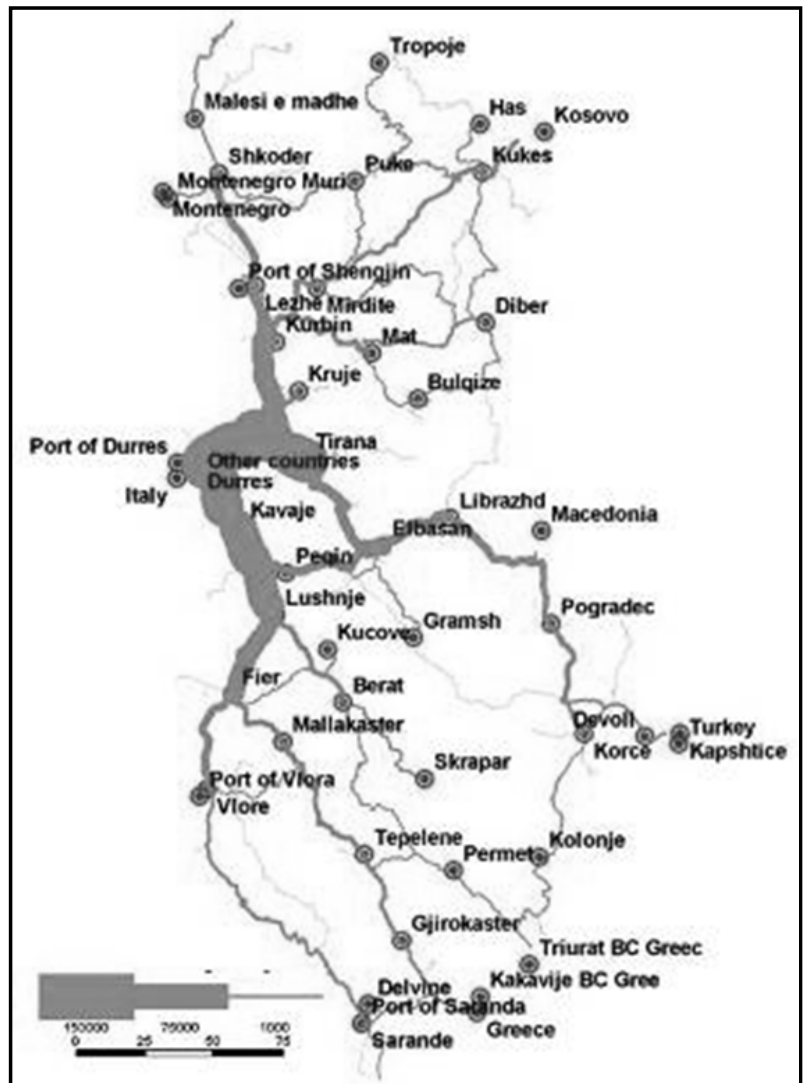

Figure 3. Passenger Traffic in the Road Network for 2010 (number of passengers / day)

Source: First Five Years Review of the Albanian National Transport Plan (antp) European Commission Europeaid / 127468 / c / ser / al Draft Final Report part I June 2010. The European Union funds this project. Louis Berger.

Some of the aforementioned corridors have been completed and currently, the Albanian road network has a total length of approximately $18,000 \mathrm{~km}$, of which $3794 \mathrm{~km}$ are defined as national roads.

\section{Data collection and processing}

The study aims to differentiate the administrative units (municipalities and districts) with varying lengths and densities (by surface and by population) of the national road network from the average of the Republic. For this purpose, the data on the surfaces, lengths of national roads and the number of population according to municipalities and counties are collected.

Municipal surface can also be found directly on the "Territorial Reform" page, but by analytical analysis and analytical control of the values obtained from this site it turns out that in some cases these surfaces contain errors. Therefore, the surfaces of the municipalities are found through GIS, based on the compensation theory using the relevant map (map 4). 


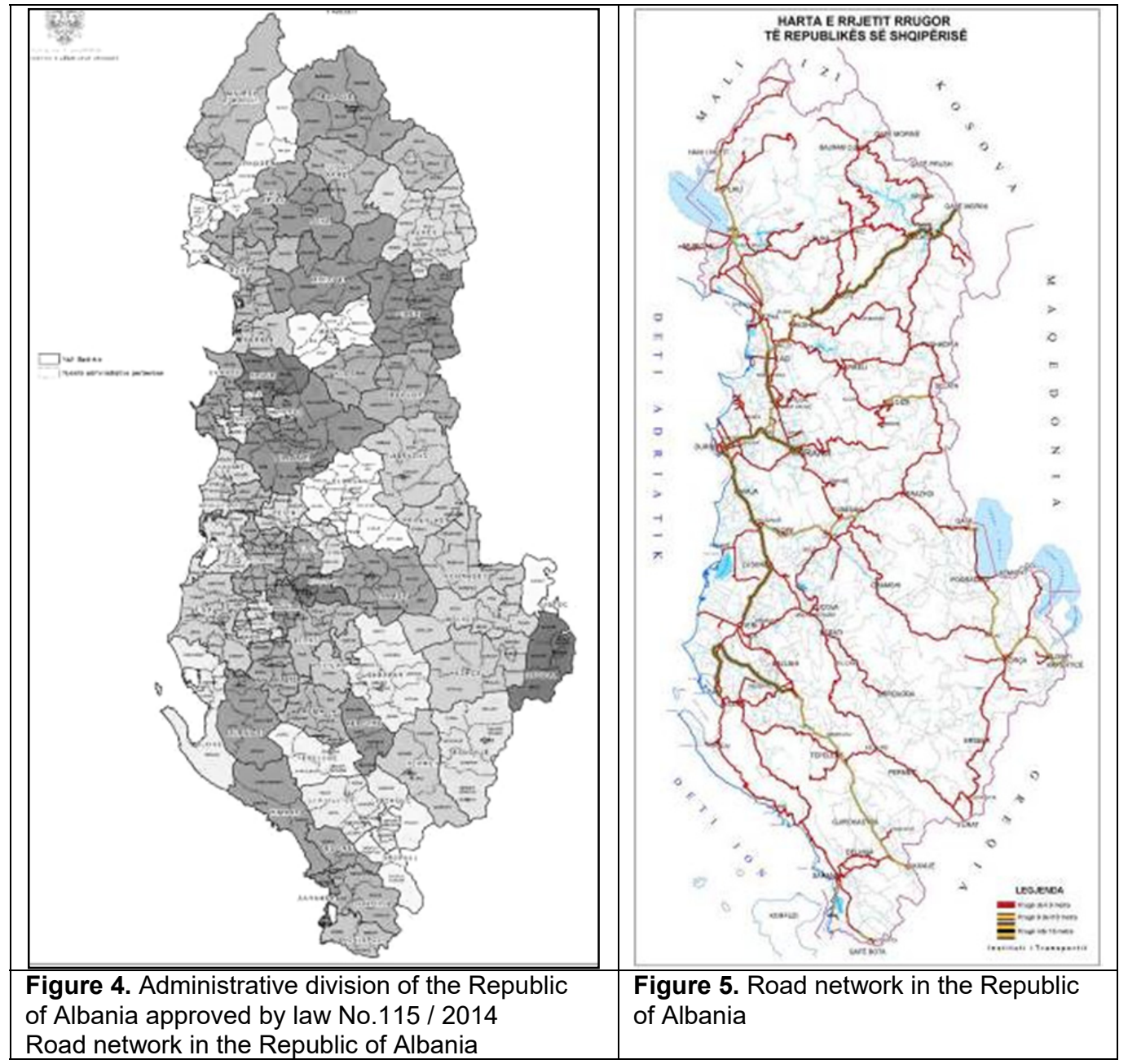

Also, from the road network map (map 5), compiled by the Ministry of Transport (Transport Institute), we have extracted the length of the main road network for each municipality, applying GIS technology and the compensation theory that takes into account the lengths of the road network of Albania provided by the Ministry of Transport.

\section{Differentiation of Municipalities and Counties According to the Length of the National Road Network}

Using the above-mentioned data, for the differentiation of the national road network of the Republic of Albania by municipalities and districs, we have calculated the average (simple and weighed) and variation indicators (variance, standard deviation, variation coefficient) according to the following formulas:

Simple Average (1):

$\mu=\left[\sum_{i=1}^{N}(X i)\right] / N$

Where:

$\mathrm{X} \mathrm{i}$ - measured / observed values 
$\mathrm{N}$ - number of measurements / observations

Weighted average (2):

$$
\mu=\frac{f_{1} x_{1}+f_{2} x_{2}+\ldots . .+f_{k} x_{k}}{f_{1}+f_{2}+\ldots .+f_{k}}=\frac{\sum f_{i} x_{i}}{\sum f_{i}}
$$

Where:

$\mathrm{Xi}$ - measured / observed values

$f_{i}$ - weights of measured / observed values,

Mode - the observed value that is repeated often during the measurements/observations (3)

When the characteristic values are given at intervals, the mode is calculated by means of the formula:

$M_{0}=X_{0}+d \frac{f m_{2}-f m_{1}}{\left(f m_{2}-f m_{1}\right)+\left(f m_{2}-f m_{3}\right)}$

$X_{0}$ The first limit of the interval mode

$d$ The width of the interval mode

$f m_{1}$ the frequency of the previous interval mode

$\mathrm{fm}_{2}$ the frequency range of the mode

$\mathrm{fm}_{3}$ the frequency of interval after mode

Mediana (4 and 5)

$X_{m}=\frac{X(n / 2)+X(n / 2+1)}{2}$ For even number of surveys / measurements (4), $\mathrm{n}$ - number of surveys / measurements

$X_{m}=\frac{X(n+1)}{2}$ For odd number of observations (5), $\mathrm{n}$ - number of surveys / measurements

Variance (6)

$\operatorname{Var}(x)=\frac{\sum\left(x_{i}-\bar{x}\right) f_{i}}{n-1}$

Variation coefficient in \% (7)

$k_{v}=\frac{\sqrt{\operatorname{Var}(x)}}{-} \times 100$

$x$

Standard deviation (8)

$$
\sigma=\sqrt{\frac{\sum_{i=1}^{N}\left(x_{i}-\bar{x}\right)^{2}}{N}}
$$

The correlation coefficient (9)

$$
r=\frac{n \sum x y-\sum x \cdot \sum y}{\sqrt{\left[n \sum x^{2}-\left(\sum x\right)^{2}\right]\left[n \sum y^{2}-\left(\sum y\right)^{2}\right]}}
$$

$r$ - Correlation coefficient

$\mathrm{x}, \mathrm{y}$ - values of the observed phenomena

$\mathrm{n}$ - Sample size. 
According to the data of 2015, in all of Albania there are $3794 \mathrm{~km}$ national roads or for each municipality, approximately $\mu=79.3 \mathrm{~km}$ [calculated by weighted average (formula 2), where: $\mathrm{fi}$ municipal surface in $\mathrm{km} 2$, and xi- the length of the national road network in $\mathrm{km}$ for each municipality], with a standard deviation $\sigma=39.4 \mathrm{~km}$ (formula 8). For values of the length of the national road system by municipalities, the value between the series (formula 5) is $\mathrm{Me}=47.1 \mathrm{~km}$ (Hasi) and the most frequently repeated value (formula 3 ), Mo $=43.5 \mathrm{~km}$ (Shijaku, Gramshi).

Over this average there are 17 municipalities (about 28\%); relatively more developed, with a larger areas, with lower, more flexible or more favorable geographic position (municipalities regional centers and transit), such as: Pogradec, Bulqizë, Vau i Dejës, Lushnjë, Himarë, Selenicë, Dibër, Vlorë, Malësia e Madhe, Tropojë, Shkodra, Mirditë, Kukës, Fier, Lezhë, Elbasan dhe Tiranë. About $72 \%$ of the municipalities (Vorë, UraVajgurore, Roskovec, Rrogozhinë, Kavaja, Libohova, Pustec, Patos, Kamza, Perrenjas, Belsh, Peqin, Sarandë, Cërrik, Delvinë, Dropull, Skrapar, Berat, Kuçovë, Gjirokastër, Kurbin, Klos, Kelcyra, Shijak, Gramsh, Memaliaj, Konispol, Puka, Has, Përmet, Maliq, Livadhja / Finiq, Divjaka, Mat, Librazhd, Devoll, Durrës, Mallakastra, Korça, Kolonjë, Fushë Arrës, Tepelena and Kruja) have a length of the national road network less than the average of the Republic.

Table 1. Differentiation of municipalities according to the length of the national road network and standard deviation

\begin{tabular}{|c|c|c|}
\hline Interval & Designation & Municipalities \\
\hline $\begin{array}{l}\text { Less than } \\
39.9 \mathrm{~km}\end{array}$ & \begin{tabular}{|l} 
Municipalities with length of the \\
national road network \\
"significantly below the average" \\
$22(36 \%)$
\end{tabular} & $\begin{array}{l}\text { Vorë, Ura Vajgurore, Roskovec, Rrogozhinë, Kavajë, } \\
\text { Libohovë, Pustec, Patos, Kamzë, Përrenjas, Belsh, Peqin, } \\
\text { Sarandë, Cërrik, Delvinë, Dropull, Skrapar, Berat, Kuçovë, } \\
\text { Gjirokastër, Kurbin, Poliçan }\end{array}$ \\
\hline $\begin{array}{l}39.9 \mathrm{~km} \mathrm{-} \\
79.3 \mathrm{~km}\end{array}$ & $\begin{array}{l}\text { Municipalities with length of the } \\
\text { national road network "below the } \\
\text { average" } 22(36 \%)\end{array}$ & $\begin{array}{l}\text { Klos, Këlcyrë, Shijak, Gramsh, Memaliaj, Konispol, Pukë, } \\
\text { Has, Përmet, Maliq, Livadhja/Finiq, Divjakë, Mat, Librazhd, } \\
\text { Devoll, Durrës, Mallakastër, Korçë, Kolonjë, Fushë Arrës, } \\
\text { Tepelenë, Krujë }\end{array}$ \\
\hline $\begin{array}{l}79.3 \mathrm{~km} \mathrm{-} \\
118.7 \mathrm{~km}\end{array}$ & $\begin{array}{l}\text { Municipalities with length of } \\
\text { national road network "above the } \\
\text { average" } 11(18 \%)\end{array}$ & $\begin{array}{l}\text { Pogradec, Bulqizë, Vau i Dejës, Lushnjë, Himarë, Selenicë, } \\
\text { Dibër, Vlorë, Malësia e Madhe, Tropojë, Shkodra }\end{array}$ \\
\hline $\begin{array}{l}\text { Over } \\
118.7 \mathrm{~km}\end{array}$ & $\begin{array}{l}\text { Municipalities with length of the } \\
\text { national road network "significantly } \\
\text { above the average" } 6(10 \%)\end{array}$ & Mirditë, Kukës, Fier, Lezhë, Elbasan, Tiranë \\
\hline
\end{tabular}

Differentiation of municipalities according to the length of the national road network and standard deviation is based on the statistical theory. Thus, according to this theory, we distinguish the municipalities with the length of the road network: significantly below the average, those with less than $(\mu-\sigma) \mathrm{km}(<39.9 \mathrm{~km})$; below the average, those with more than $(\mu-\sigma) \mathrm{km}$ and less than $(\mu)$ $\mathrm{km}(39.9 \mathrm{~km} \div 79.3 \mathrm{~km})$; above the average, those with more than $(\mu) \mathrm{km}$ and less than $(\mu+\sigma) \mathrm{km}$ $(79.3 \mathrm{~km} \div 118.7 \mathrm{~km})$ and significantly above the average, those with more than $(\mu+\sigma) \mathrm{km}(>$ $118.7 \mathrm{~km})(1)$.

Currently, in all Albania there is an average of $\mu=332.4 \mathrm{~km}$ national roads for each district (calculated by weighted average, where: $\mathrm{fi}$ - surface of districts in $\mathrm{km}^{2}$, and xi-lengths of national road network in $\mathrm{km}$ for each district) with a standard deviation $\sigma=89.7 \mathrm{~km}$. Above this average there are 5 districts (about 42\%) such as: Elbasan, Korça, Fier, Shkodra and Vlora. About 58\% of the districts (Berat, Durrës, Tirana, Debar, Gjirokastra, Kukës and Lezha) have a national road length less than the average of the Republic.

In analogy with the differentiation of municipalities, in Overview 2 is given the differentiation of the districts according to the length of the national road network and the standard deviation. districts with the length of the national road network: significantly below the average, those with less than $(\mu$ $\sigma) \mathrm{km}(<242.7 \mathrm{~km})$; below the average, those with more than $(\mu-\sigma) \mathrm{km}$ and less than $(\mu) \mathrm{km}(242.7$ $\mathrm{km} \div 332.4 \mathrm{~km})$; above the average, those with more than $(\mu) \mathrm{km}$ and less than $(\mu+\sigma) \mathrm{km}(332.4 \mathrm{~km}$ $\div 422.1 \mathrm{~km})$ and significantly above the average, those with more than $(\mu+\sigma) \mathrm{km}(>422.1 \mathrm{~km})$. 
Table 2. Differentiation of districts according to the length of the national road network and standard deviation

\begin{tabular}{|l|l|l|}
\hline Interval & Designation & Municipalities \\
\hline $\begin{array}{l}\text { With less than } \\
242.7 \mathrm{~km}\end{array}$ & $\begin{array}{l}\text { Circuits with length of the national road network } \\
\text { "significantly below the average" 2 (about 17\%) }\end{array}$ & Berat, Durrës \\
\hline $\begin{array}{l}\text { with } 242.7 \mathrm{~km}- \\
332.4 \mathrm{~km}\end{array}$ & $\begin{array}{l}\text { Districts with length of the national road network "below the } \\
\text { average" 5 (about 41\%) }\end{array}$ & $\begin{array}{l}\text { Tiranë, Dibër, Gjirokastër, } \\
\text { Kukës, Lezhë }\end{array}$ \\
\hline $\begin{array}{l}\text { with } 332.4 \mathrm{~km}- \\
422.1 \mathrm{~km}\end{array}$ & $\begin{array}{l}\text { Districts with length of national road network "above the } \\
\text { average" 3 (about 25\%) }\end{array}$ & Elbasan, Korçë, Fier \\
\hline $\begin{array}{l}\text { With above 422.1 } \\
\mathrm{km}\end{array}$ & $\begin{array}{l}\text { Districts with length of the national road network } \\
\text { "significantly above the average" 2 (about 17\%) }\end{array}$ & Shkodër, Vlorë \\
\hline
\end{tabular}

Depending on the geographical position, the size of the urban center and the degree of economic development depend on the number of regional and national roads that join in the urban center and cross the territory of the municipality.

\section{Differentiation of Municipalities and Districts According to the Density of the National Road Network in Relation to the Area}

Even for this type of differentiation, statistical indicators were used, calculated according to formulas (1-9) utilizing data on the density of the national road network for each municipality and district.

According to the data of 2015 , in all of Albania there is an average $\mu=151.3 \mathrm{~km} / 1000 \mathrm{~km}^{2}$ national road per municipality (calculated by simple mean (formula 1)] with a standard deviation $\sigma=$ $94.8 \mathrm{~km} / 1000 \mathrm{~km}^{2}$. above this average there are 21 municipalities (about $34.4 \%$ ), such as: Himarë, Vorë, Tirana, Vau i Dejës, Selenicë, Tepelenë, Elbasan, Vlorë, Konispol, Divjakë, Durrës, Mallakastër, Fier, Kuçovë, Krujë, Lushnjë, Patos, Lezhë, Saranda, Shijak and Kamza.

From the differentiation of the municipalities according to the density of the national road network to the surface and the standard deviation, we distinguish the municipalities with density of the road network: significantly below the average, those with less than $(\mu-\sigma) \mathrm{km} / 1000 \mathrm{~km}^{2}(<56.5$ $\mathrm{km} / 1000 \mathrm{~km}^{2}$; ; below the average, those with more than $(\mu-\sigma) \mathrm{km} / 1000 \mathrm{~km}^{2}$ and less than $(\mu)$ $\mathrm{km} / 1000 \mathrm{~km}^{2}\left(56.5-151.3 \mathrm{~km} / 1000 \mathrm{~km}^{2}\right)$; above the average, those with more than $(\mu) \mathrm{km} /$ $1000 \mathrm{~km}^{2}$ and less than $(\mu+\sigma) \mathrm{km} / 1000 \mathrm{~km}^{2}\left(151.3-246.1 \mathrm{~km} / 1000 \mathrm{~km}^{2}\right)$ and significantly above the average, $\sigma) \mathrm{km} / 1000 \mathrm{~km}^{2}(>246.1 \mathrm{~km} / 1000 \mathrm{~km} 2)$ (Ref. 3).

Table 3. Differentiation of municipalities according to the density of the national road network and standard deviation

\begin{tabular}{|c|c|c|}
\hline Interval & Designation & Municipalities \\
\hline \begin{tabular}{lr|} 
With & less than \\
56.5 & $\mathrm{~km} / 1000$ \\
$\mathrm{~km}^{2}$ & \\
\end{tabular} & $\begin{array}{l}\text { Municipalities with density of the } \\
\text { national road system significantly } \\
\text { below the average }(1.6 \%)\end{array}$ & Skrapar \\
\hline $\begin{array}{l}56.5-151.3 \\
\mathrm{~km} / 1000 \mathrm{~km}^{2}\end{array}$ & $\begin{array}{l}\text { Municipalities with density of the } \\
\text { national road system below } \\
\text { average }(64 \%)\end{array}$ & $\begin{array}{l}\text { Gramsh, Kavajë, Dropull, Përrenjas, Librazhd, Përmet, } \\
\text { Maliq, Libohovë, Kolonjë, Gjirokastër, Korçë, Berat, Pukë, } \\
\text { Ura Vajgurore, Rrogozhinë, Pustec, Dibër, Tropojë, Klos, } \\
\text { Mat, Has, Peqin, Malësia e Madhe, Memaliaj, Belsh, } \\
\text { Bulqizë, Delvinë, Roskovec, Këlcyrë, Pogradec, Shkodra, } \\
\text { Fushë Arrës, Livadhja/Finiq, Kukës, Cërrik, Devoll, Mirditë, } \\
\text { Kurbin, Poliçan }\end{array}$ \\
\hline $\begin{array}{l}151.3-246.1 \\
\mathrm{~km} / 1000 \mathrm{~km}^{2}\end{array}$ & $\begin{array}{l}\text { Municipalities with density of } \\
\text { national road system above the } \\
\text { average }(26.2 \%)\end{array}$ & $\begin{array}{l}\text { Himarë, Vorë, Tiranë, Vau i Dejës, Selenicë, Tepelenë, } \\
\text { Elbasan, Vlorë, Konispol, Divjakë, Durrës, Mallakastër, } \\
\text { Fier, Kuçovë, Krujë, Lushnjë. }\end{array}$ \\
\hline $\begin{array}{l}\text { With more than } \\
\text { se } 246.1 \mathrm{~km} / \mathrm{km}^{2}\end{array}$ & $\begin{array}{l}\text { Municipalities with density of the } \\
\text { national road system significantly } \\
\text { above average }(8.2 \%)\end{array}$ & Patos, Lezhë, Sarandë, Shijak, Kamzë \\
\hline
\end{tabular}


Currently, in all of Albania there is an average of $\mu=138.6 \mathrm{~km} / 1000 \mathrm{~km}^{2}$ national road for each district [calculated by simple mean], with a standard deviation $\sigma=47.3 \mathrm{~km} / 1000 \mathrm{~km}^{2}$. Above this average there are 5 districts (about $41.65 \%$ ), such as Lezha, Tirana, Vlora, Durrës and Fier.

By analogy with the differentiation of municipalities, in Overview 4 is given the differentiation of the districts according to the density of the national road network and the standard deviation. Municipalities with road network densities: significantly below the average, those with less than $(\mu$ $\sigma) \mathrm{km} / 1000 \mathrm{~km}^{2}\left(<91.3 \mathrm{~km} / 1000 \mathrm{~km}^{2}\right)$; below the average, those with more than $(\mu-\sigma) \mathrm{km} / 1000$ $\mathrm{km}^{2}$ and less than $(\mu) \mathrm{km} / 1000 \mathrm{~km}^{2}\left(91.3 \mathrm{~km} / 1000 \mathrm{~km}^{2} \div 138.6 \mathrm{~km} / 1000 \mathrm{~km}^{2}\right)$; above the average, those with more than $(\mu) \mathrm{km} / 1000 \mathrm{~km}^{2}$ and less than $(\mu+\sigma) \mathrm{km} / 1000 \mathrm{~km}^{2}(138.6 \mathrm{~km} /$ $\left.1000 \mathrm{~km}^{2} \div 185.9 \mathrm{~km} / 1000 \mathrm{~km}^{2}\right)$ and significantly above the average, those with more is $(\mu+\sigma)$ $\mathrm{km} / 1000 \mathrm{~km}^{2}\left(>185.9 \mathrm{~km} / 1000 \mathrm{~km}^{2}\right)$.

Table 4. Differentiation of districts according to the density of the national road network and standard deviation

\begin{tabular}{|l|l|l|}
\hline Interval & Designation & Districts \\
\hline $\begin{array}{l}\text { With less than } 91.3 \\
\mathrm{~km} / 1000 \mathrm{~km}^{2}\end{array}$ & $\begin{array}{l}\text { Municipalities with density of national road network } \\
\text { significantly below average (8:35\%) }\end{array}$ & Berat \\
\hline $\begin{array}{l}91.3 \quad 138.6 \\
\mathrm{~km} / 1000 \mathrm{~km}^{2}\end{array}$ & $\begin{array}{l}\text { Municipalities with density of national road network } \\
\text { below average (50\%) }\end{array}$ & $\begin{array}{l}\text { Dibër, Elbasan, Gjirokastër, } \\
\text { Korçë, Kukës, Shkodër }\end{array}$ \\
\hline $\begin{array}{l}138.6 \quad 185.9 \\
\mathrm{~km} / 1000 \mathrm{~km}^{2}\end{array}$ & $\begin{array}{l}\text { Districts with density of national road network above } \\
\text { the average (25\%) }\end{array}$ & Lezhë, Tiranë, Vlorë \\
\hline $\begin{array}{l}\text { With more than 185.9 } \\
\mathrm{km} / \mathrm{km}^{2}\end{array}$ & $\begin{array}{l}\text { Districts with density of national road network } \\
\text { significantly above average }(16.65 \%)\end{array}$ & Durrës, Fier \\
\hline
\end{tabular}

\section{Differentiation of Municipalities and Districts According to the Density of National Road Network in Relation to the Population}

In order to realize this kind of differentiation of municipalities and districts, the density of the national road network to the population was calculated with the formula:

$D=\left[L^{*} 10,000\right] / P$, where:

$\mathrm{L}-$ Length of road network in $\mathrm{km}$;

$\mathrm{P}$ - number of population (according to INSTAT data, 2014)

According to the data of 2014, in all of Albania there were averagely $\mu=57.5 \mathrm{~km} / 10,000$ national road per municipality (calculated by simple average), with a standard deviation $\sigma=28.8 \mathrm{~km}$ / 10,000 inhabitants. Over this average there are 12 municipalities (about 19.5\%) such as Selenica, Konispol, Libohova, Mirdita, Tropoja, Kolonja, Pustec, Këlcyra, Dropull, Tepelena, Fushë Arrës and Himara.

Table 5. Differentiation of municipalities according to the density of the national road network in relation to population and standard deviation

\begin{tabular}{|c|c|c|}
\hline Interval & Designation & Municipalities \\
\hline $\begin{array}{l}\text { With less than } \\
28.7 \quad \mathrm{~km} \\
10,000 \\
\text { inhabitants }\end{array}$ & $\begin{array}{l}\text { Municipalities with density of the } \\
\text { national road network below the } \\
\text { average }(70 \%)\end{array}$ & $\begin{array}{l}\text { Vorë, Kamzë, Tiranë, Durrës, Kavajë, Berat, Ura } \\
\text { Vajgurore, Roskovec, Rrogozhinë, Kurbin, Shkodër, } \\
\text { Korçë, Peqin, Përrenjas, Patos, Cërrik, Lushnje, Vlorë, } \\
\text { Elbasan, Fier, Kuçovë, Belsh, Sarandë, Maliq, Shijak, } \\
\text { Pogradec, Krujë, Gjirokastër, Divjakë, Dibër, Gramsh, } \\
\text { Librazhd, Lezhë, Mat, Skrapar, Devoll, Klos, } \\
\text { Mallakastër, Bulqizë, Kukës, Vau - Dejës, Has }\end{array}$ \\
\hline $\begin{array}{l}28.7-57.5 \\
\mathrm{~km} / 10,000 \\
\text { inhabitants }\end{array}$ & $\begin{array}{l}\text { Municipalities with density of the } \\
\text { national road network above the } \\
\text { average }(11.5 \%)\end{array}$ & $\begin{array}{l}\text { Poliçan, Delvinë, M. e Madhe, Memaliaj, Pukë, Përmet, } \\
\text { Finiq }\end{array}$ \\
\hline $\begin{array}{l}\text { With more than } \\
57.5 \mathrm{~km} / 10,000 \\
\text { inhabitants }\end{array}$ & $\begin{array}{l}\text { The municipalities with density of the } \\
\text { national road network significantly } \\
\text { above the average }(19.5 \%)\end{array}$ & $\begin{array}{l}\text { Selenicë, Konispol, Libohovë, Mirditë, Tropojë, Kolonjë, } \\
\text { Pustec, Këlcyrë, Dropull, Tepelenë, F. - Arrës, Himarë }\end{array}$ \\
\hline
\end{tabular}


From the differentiation of the municipalities according to the density of the national road network in relation to the population, and the standard deviation, we distinguish the municipalities with density of the national road network in relation to the population: significantly below the average, those with less $28.7 \mathrm{~km} / 10,000$ inhabitants; below the average, those with $28.7 \mathrm{~km} \mathrm{/} \mathrm{10,000} \mathrm{inhabitants} \mathrm{\div}$ $57.5 \mathrm{~km} / 10,000$ inhabitants; above the average, those with $57.5 \mathrm{~km} / 10,000$ inhabitants $\div 86.3 \mathrm{~km}$ / 10,000 inhabitants and significantly above the average, those with more than $86.3 \mathrm{~km} / 10000$ inhabitants (see Figure 5).

Table 6. Differentiation of districts according to density of the national road network in relation to population and standard deviation

\begin{tabular}{|l|l|l|}
\hline Interval & Designation & Districts \\
\hline $\begin{array}{l}\text { With less than } 7.4 \mathrm{~km} / \\
10,000 \text { inhabitants }\end{array}$ & $\begin{array}{l}\text { Districts with density of national road network } \\
\text { significantly below the average }(16.7 \%)\end{array}$ & Tiranë, Durrës \\
\hline $\begin{array}{l}7.4-11.5 \mathrm{~km} / 10,000 \\
\text { inhabitants }\end{array}$ & $\begin{array}{l}\text { Districts with density of national road network } \\
\text { below the average }(8.3 \%)\end{array}$ & Berat \\
\hline $\begin{array}{l}11.5-30.4 \mathrm{~km} / 10,000 \\
\text { banorë }\end{array}$ & $\begin{array}{l}\text { Districts with density of national road network } \\
\text { above the average }(58.3 \%)\end{array}$ & $\begin{array}{l}\text { Elbasan, Fier, Korçë, Shkodër, } \\
\text { Dibër, Lezhë, Vlorë }\end{array}$ \\
\hline $\begin{array}{l}\text { With more than } 30.4 \mathrm{~km} / \\
10,000 \text { inhabitants }\end{array}$ & $\begin{array}{l}\text { Districts with density of the national road network } \\
\text { significantly above average }(16.7 \%)\end{array}$ & Kukës, Gjirokastër \\
\hline
\end{tabular}

By analogy with the differentiation of municipalities, in Overview 6, the differentiation of districts according to density of the national road network in relation to the population and the standard deviation ( $\mu=11.5 \mathrm{~km} / 10,000$ inhabitants and $\sigma=4.1 \mathrm{~km} / 10,000$ inhabitants).

Above the average of the Republic $\mu=11.5 \mathrm{~km} / 10,000$ inhabitants, there are 9 districts or $75 \%$ of the total number of districts. The districts of Tirana, Durrës and Berat have the density of the national road network in relation to the number of population, lower than the average of the Republic.

\section{Differentiation of Municipalities and Districts According to the Density of the National Road Network in Relation to Surface and Population. Correlation Analysis}

By statistical processing it results that $41.5 \%$ of the total number of municipalities (Kavaja Berat, Ura Vajgurore, Roskovec, Rrogozhinë, Kurbin, Shkoder, Korce, Peqin, Përrenjas, Cërrik, Belsh, Maliq, Pogradec, Gjirokastra, Dibra, Gramsh, Librazhd, Mat, Skrapar, Devoll, Klos, Bulqiza, Kukës, Has) have the density of the national road network (in relation to the surface and the population), "significantly below average" and "below average" of the Republic.

Berat is the district with density of national road network (by surface area and population), "below average", while Tirana and Durres are districts with density of national road network (per population) "significantly below average" of the Republic.

For more specialized analyzes, we have put in report the values for the surface of the municipalities and the length of the national road network within them.

The value of the coefficient of correlation ( $r=0.7748$, calculated according to formula 9) indicates a considerable positive relation between the surfaces of the municipalities and the length of the national road network within them, which means that in municipalities with larger surface area, the length of the road is greater, provided that relief is field-hilly and with valleys.

The regression coefficient in the equation $Y=10.277+0.108 \mathrm{X}$, shows that, theoretically, with the increase of surface per $100 \mathrm{~km}^{2}$, the length of the national road network increases by $10.8 \mathrm{~km}$.

We have also mapped the values for the population of the municipalities and the length of the national road network within them. The value of the correlation coefficient $(r=0.5295)$ indicates a somewhat strong relation between the number of population and the length of the national road network in the municipality. 


\section{Conclusions}

Albanian road network has a total length of approximately $18,000 \mathrm{~km}$., of which $3794 \mathrm{~km}$ are classified as national roads. The distribution of this road network is different and depends on the physical and geographical factors and socio-economic factors. The density of total road network is about $630 \mathrm{~km} / 1000 \mathrm{~km}^{2}$, while the density of the national road network is about $130 \mathrm{~km} / 1000 \mathrm{~km}$, value that ranks Albania in the last group of global classification together with Romania and Bulgaria, but after all Balkan countries.

Based on some statistical indicators, the study assesses and classifies Albania's national road network according to administrative organization (municipalities and counties) approved by Law no. 115/2014. Data sources are road maps and topographic maps at scales 1: 100,000 and 1:200,000, and the data received by the Ministry of Transport and Infrastructure and the Ministry of Local Government. Maps and images are processed in ArcGIS 10.2, where are digitized road nodes and lines and other geographic objects associated with the road network.

Each municipality has an average $79.3 \mathrm{~km}$ of national road $\left(151.3 \mathrm{~km} / 1000 \mathrm{~km}^{2}\right.$ with a standard deviation $94.8 \mathrm{~km} / 1000 \mathrm{~km}^{2}$ and $57.5 \mathrm{~km} / 10,000$ inhabitants with a standard deviation $28.8 \mathrm{~km} / 10,000$ inhabitants), while each county has an average $332.4 \mathrm{~km}$ of road national (138.6 $\mathrm{km} / 1000 \mathrm{~km}^{2}$ with a standard deviation $47.3 \mathrm{~km} / 1000 \mathrm{~km}^{2}$ and $11.5 \mathrm{~km} / 10,000$ inhabitants). Over the average there are 17 municipalities (28\%) [Among which 6 municipalities (10\%) have a length of the national road network "significantly above average"] and 5 counties (42\%). While under this average there are 44 municipalities (72\%) [Among which, 22 municipalities (36\%) have a length of the national road network "significantly under average"] and 7 counties (58\%) [Berat, Durres, Tirana, Dibër, Gjirokastra and Lezha, among which Berat and Durres have a length of the national road network "significantly below average"].

Approximately $41.5 \%$ of the total number of municipalities [Kavajë, Berat, Ura Vajgurore, Roskovec, Rrogozhinë, Kurbin, Shkodër, Korçë, Peqin, Prrenjas, Cërrik, Belsh, Maliq, Pogradec, Gjirokaster, Dibër, Gramsh, Librazhd, Mat, Skrapar, Devoll, Klos, Bulqizë, Kukës, Has] have the density of the national road network (related to the surface and the population), "significantly below average" and "below average" of the Albania. Berat county has national road network density (related to the surface and the population) "below average", while the Tirana county and Durres county has road network density (related to the population) "significantly below average" of Albania.

The unequal development of the road network is one of the strongest reasons for the unequal economic development of different regions of Albania. Inadequacy of road infrastructure is also a major cause for the high level of pollution in urban areas.

\section{Recommendations}

- The density of the overall road network is about $630 \mathrm{~km} / 1000 \mathrm{~km} 2$, while the density of the national road network is about $130 \mathrm{~km} / 1000 \mathrm{~km} 2$, ranking Albania in the last group of classification at world level, such as Romania and Bulgaria, but behind all the Balkan countries.

- There are on average $79.3 \mathrm{~km}$ of national roads per city and $332.4 \mathrm{~km}$ of national roads for each district in all of Albania. Above the average, there are 17 municipalities $(28 \%)$, among which, 6 municipalities $(10 \%)$ have a national road network "significantly above average"] and 5 districts (42\%) such as Elbasan, Korca, Fier, Shkodra and Vlora. While, below average, there are 44 municipalities (72\%), of which 22 municipalities (36\%) have a national road network "significantly below average"] and 7 districts $(58 \%)$ such as Berat, Durrës, Tirana, Dibra, Gjirokastra, Kukës and Lezha. Also, in all of Albania, there is an average of $151.3 \mathrm{~km} / 1000 \mathrm{~km}^{2}$ national road per city with a standard deviation of $94.8 \mathrm{~km}$ $/ 1000 \mathrm{~km}^{2}$ and $138.6 \mathrm{~km} \mathrm{/} 1000 \mathrm{~km}^{2}$ national road for each district with a standard deviation of $47.3 \mathrm{~km} / 1000 \mathrm{~km}^{2}$. Above average there are 21 municipalities (about $34.4 \%$ ) [Himarë, Vorë, Tirana, Vau i Dejes, Selenica, Tepelena, Elbasan, Vlorë, Konispol, Divjaka, Durrës, Mallakastra, Fier, Kuçovë, Krujë, Lushnjë, Patos, Lezhë, Sarandë, Shijak and Kamza] and 5 districts (about 41.65\%) [Lezha, Tirana, Vlora, Durrës and Fier]. 
- For each municipality there are an average of $57.5 \mathrm{~km} \mathrm{/} \mathrm{10,000} \mathrm{inhabitants} \mathrm{with} \mathrm{a}$ standard deviation of $28.8 \mathrm{~km} \mathrm{/} \mathrm{10,000} \mathrm{inhabitants,} \mathrm{while} \mathrm{for} \mathrm{each} \mathrm{district} \mathrm{there} \mathrm{are} \mathrm{an}$ average of $11.5 \mathrm{~km} / 10000$ inhabitants. Above this average there are 12 municipalities (about 19.5\%) (Selenica, Konispol, Libohova, Mirdita, Tropoja, Kolonja, Pustec, Këlcyra, Dropull, Tepelena, F. - Arrës and Himara) and 9 districts or $75 \%$ of the total number of districts. The districts of Tirana, Durrës and Berat have density of the national road network in relation to the number of population, lower than the average of the Republic.

- Municipalities with density of road network (in relation to surface and population), "significantly below average" and "below average", account for about $41.5 \%$ of their total number [Kavaja, Berat, Ura Vajgurore, Roskovec, Rrogozhina, Kurbin, Shkodër, Korçë, Peqin, Perrenjas, Cërrik, Belsh, Maliq, Pogradec, Gjirokastër, Debar, Gramsh, Librazhd, Mat, Skrapar, Devoll, Klos, Bulqizë, Kukës, Has]. Berat is the district with density of road network (by surface and population) "below average", while Tirana and Durres are districts with density of road networks (by population) "significantly below average".

- The correlation coefficient value $(r=0.7748)$ indicates a significant positive correlation between the areas of the municipalities and the length of the national road network within their boundaries, provided that the relief is field-hilly and with valleys. Likewise, the value of the correlation coefficient $(r=0.5295)$ indicates a somewhat strong relation between the number of population and the length of the national road network in the municipality.

- Analysis of statistical indicators shows that the distribution of the national road network in the Republic of Albania is not uniform. This is conditioned by physical-geographic and socio-economic factors. Uneven development of the transport network is one of the strongest reasons for the uneven economic development of the various provinces of the country. There is a rigorous proportional relationship between the poverty rate and the level of infrastructure quality. For this, the northern and northeastern parts of the country can be taken as an example. Insufficient road infrastructure is also a major cause for high levels of pollution in urban areas. Typical example for this is the city of Tirana where the concentration of construction and infrastructure development within the small roundabout has caused pollution levels up to ten times higher than the norm

- In the future, care should be taken to increase the length of the national road network to $41.5 \%$ of municipalities [Kavaja, Berat, Ura Vajgurore, Roskovec, Rrogozhina, Kurbin, Shkodra, Korça, Peqin, Perrenjas, Cerrik, Belsh, Maliq, Pogradec , Gjirokastra, Dibra, Gramsh, Librazhd, Mat, Skrapar, Devoll, Klos, Bulqiza, Kukës, Has] and in 25\% of the districts [Tirana, Durrës and Berat].

\section{References}

Anantsuksomsri S., Tontisirin N., 2015. The impacts of mass transit improvements on residential land development values: evidence from the Bangkok Metropolitan Region, Urban Pol. Res., 33 (2) (2015): 195-216,doi:10.1080/08111146.2014.982791.

Armstrong R.J., Rodriguez D. A., 2006. An evaluation of the accessibility benefits of commuter rail in eastern Massachusetts using spatial hedonic price functions, Transportation, $33(1)(2006): 21-43$, doi: 10.1007/s11116-005-0949-x

Atack J., F., Bateman M., Haines and Margo R. A., 2010. Did railroads induce or follow economic growth? Urbanization and population growth in the American Midwest, 1850-1860. Social Science History 34 (2): $171-197$.

Badigar G. S., Badigar K. R., 2003. Impact of Transportation Development on Industrialisation in Goa.In B.C. Vaidya (Ed.), Geography of Transport development in India: 250-272). New Delhi: Concept Publishing Company.

Banister D., Berechman J., 2001. Transport investment and the promotion of economic growth. Journal of Transport Geography 9: 209-218.

Bollinger C. R., Ihlanfeldt K. R., 1997. The impact of rapid rail transit on economic development: The case of Atlanta's MARTA. Journal of Urban Economics 42(2): 179-204.

Cervero, R 2003, Effects of light and commuter rail transit on land prices: experiences in San Diego County, University of California, Berkeley, CA 94720-1850, robertc@uclink.berkeley.edu. 
Du H., Mulley C., 2007. Transport accessibility and land value: a case study of tyne and wear, doi:10.1.1.111.4163

Forman R. T. T., Sperling D., Bissonette J. A., Clevenger A. P., Cutshall A. P., Dale V. H., Fahrig L., France R., Goldman C. R., Heanue K., Jones J. A., Swanson F. J., Turrentine T., Winter T. C., 2003. Road Ecology Science and Solutions, Island Press, Washington.

Garrett T.A., 2004. Light-Rail Transit in America: Policy Issues and Prospects for Economic Development, Federal Reserve Bank of St. Louis, https://www.stlouisfed.org.pdf.

Harta dhe të dhëna për ndarjen administrative sipas ligjit 115/2014, të Ministrisë për Çështjet Vendore, Tiranë 2015.

Harta rrugore të shkallëve 1: 100000 e 1:200000, të IGU dhe Institutit të Transportit, Tiranë.

Harta topografike të shkallëve 1: 100000 të IGU, Tiranë.

Herman G.V., 2009. The Impact of Road Infrastructure on the Natural Someş Plain, in Analele Universităţii din Oradea, Seria Geografie, Oradea, Tom XIX: 195 - 200.

Laakso S., 1992. Public transport investment and residential property values in Helsinki, Scand. Hous. Plann. Res., 9 (4) (1992), pp. 217-229, doi: 10.1080/02815739208730308

Ligji nr. 115/2014, datë 31.7.2014. "Për ndarjen administrative - territoriale të njësive të qeverisjes vendore në Republikën e Shqipërisë".

Medda F., Modelewska M., 2010. Land Value Capture as a Funding Source for Urban Investment, The Warsaw Metro System /LAND_VALUE_CAPTURE.pdf.

Mclntosh J., Trubka R., Newman P., 2014. Can value capture work in a car dependent city? Willingness to pay for transit access in Perth, Western Australia, Transport. Res. Part A Policy Pract., 67 (2014), pp. 320339, doi:10.1016/2014.07.008

Ministria e Mjedisit dhe Planifikimit Hapësinor, Prishtinë, 2017.

Mulley C., 2014. Accessibility and residential land value uplift: identifying spatial variations in the accessibility impacts of a bus transitway, Urban Stud., 51 (8) (2014): 1707-1724, doi:10.1177/0042098013499082

Rishikimi i parë pesëvjeçar i planit Kombëtar Shqiptar të transportit (antp). Komisioni Europian Europeaid/127468/c/ser/al. Drafti i raportit përfundimtar pjesa I qershor 2010. Ky projekt është financuar nga Bashkimi Europian.

Seiler A., 2001. Ecological Effects of Roads, A review. Introductory Research Essay No. 9. Department of Conservation Biology, Swedish University of Agricultural Science, Upsalla.

Smart Cities Plan 2017. City deals, Retrieved from https://cities.dpmc.gov.au/city-deals.

Steiner F., Butler K., 2007. Planing and Urban Design Standards, University of Texas at Austin: $143-181$.

Stewart A., Stewart E., 1996. A Decision-Making Technique for Choosing a Psychology Internship, Professional Psychology: Research and Practice, Vol. 27, No. 5: 521-526.

Sun J., Chen T., Cheng Z., Wang C.C., Ning X., 2017. A financing mode of Urban Rail transit based on land value capture: a case study in Wuhan City, Transport Pol., 57 (2017): 59-67.

Sharma R., Newman P., Matan A., 2015. Urban Rail - India's great opportunity for sustainable urban development, European Transport Conference, Frankfurt, http://abstracts.aetransport.org/paper/index/id/4683/confid/20.

Ministria e Transportit dhe Infrastrukturës, Tiranë 2015,Të dhëna mbi gjatësitë e rrjetit rrugor në Shqipëri.

Umoren V., Ikurekong E. E., Emmanuel A., Udida A. A., 2009. Development Envelopment of Road Infrastructure as a Tool of Transforming Ibiono Ibom Local Government Area.Global Journal of Social Sciences, 8(2): 53-59.

Yankaya U., 2004. Modeling the Impacts of Izmir Subway on the Values of Residential Property Using Hedonic Price Model, (Master's thesis) doi: 10.1.1.427.4661.

Zhong H., Li W., 2016. Rail transit investment and property values: an old tale retold, Transport Policy, 51 (2016): 33-48, doi: 10.1016/2016.05.007. 